\section{Concealed Affair of Allergic Rhinitis and Somnambulism through a Middle Man}

\section{Akhil Paul ${ }^{1 *}$ and Susana Mathew ${ }^{2}$ \\ ${ }^{1}$ Department of Pulmonary Medicine, MOSC Medical Mission Hospital, Kun- namkulam, Kerala, India}

${ }^{2}$ Department of Otorhinolaryngology, MOSC Medical Mission Hospital, Kunnamkulam, Kerala, India

\begin{abstract}
Obstructive Sleep Apnoea is common in children as well. It is strongly associated with parasomnias, including sleep terror, sleep walking etc. In this case report, we are discussing about a boy who was referred to us for the evaluation and management of sleep walking. Enlarged adenoid and tonsil, secondary to allergic disease was found to be causing Obstructive Sleep Apnoea in him, causing a trigger for the sleep walking. Here we are highlighting the importance of controlling the allergic disease in such children, which can even result in the avoidance of invasive surgical interventions like adenotonsillectomy.
\end{abstract}

\section{Case Report}

A 12 year old boy was brought to us with history of waking up with a shriek cry, after 2-3 hours of sleep and then walking to and fro in the room with laboured breathing and coughing. He has been having similar episodes, about twice or thrice in a week, for the last 3 months. The boy did not have any memory of the event and he sleeps peacefully, once forcefully taken to the bed by his parents. There was no history of seizure like movements or micturition during the episodes. The boy was otherwise normal, active and good in studies and socially interactive. He was asymptomatic in between the episodes. On detailed history taking, it was noticed that the boy was suffering from intermittent episodes of running nose and sneezing for many years and his symptoms had increased for the last 3 months. He did not snore, but used to mouth breath while sleeping. There was no history of easy fatiguability, observed apnoea or increased day time somnolescence. He was of moderate built. There were no cranio-facial abnormalities. Naso-Pharyngeo Laryngeal (NPL) scopy showed grade 2 adenoids and tonsils.

*Corresponding author: Akhil Paul, Department of Pulmonary Medicine, MOSC Medical Mission Hospital, Kunnamkulam, Kerala, India, E-mail: akhil_pauli@ yahoo.com

Citation: Paul A, Mathew S (2020) Concealed Affair of Allergic Rhinitis and Somnambulism through a Middle Man. J Pulm Med Respir Res 6: 037.

Received: July 16, 2020; Accepted: August 18, 2020; Published: August 25, 2020

Copyright: @ 2020 Paul A, et al.. This is an open-access article distributed unde the terms of the Creative Commons Attribution License, which permits unrestricted use, distribution, and reproduction in any medium, provided the original author and source are credited.
He underwent polysomnography for the evaluation of his sleep disorder. He had a total sleep time of 370 minutes with sleep efficiency of $88.4 \%$. But the time he spent on REM sleep was only $2.8 \%$ of the total sleep period. His Apnoea Hypopnea Index (AHI) was 9.0, which was abnormal for his age. AHI during the REM sleep period was 30 . His heart rate fluctuated from 57 beats $/ \mathrm{min}$ to 134 beats $/ \mathrm{min}$. His average $\mathrm{SpO} 2$ during the sleep was $97 \%$ and the minimum $\mathrm{SpO} 2$ associated with a respiratory event was $83 \%$. There was no snoring. He did not have the somnambulism episode during the study.

As enlarged adenoids and tonsils, especially in the back ground of allergic rhinitis constitutes a major cause for sleep apnoea in children, he was advised to undergo adeno-tonsillectomy. At the same time he was initiated on Mometazone nasal spray 50ug once daily and Montelukast, along with anti-histamines for a short duration. He was advised to follow the anti-allergy measures strictly.

The boy's allergic symptoms improved on the medication and he stopped mouth breathing while sleeping. There were no episodes of somnambulism thereafter. Re-assessment showed that the adenoids had significantly reduced in size.

\section{Discussion}

Obstructive sleep apnoea is not a rare disease in children. The estimated prevalence of snoring in children is about 3 to 12 percent and the prevalence of OSA is about 1 to $10 \%$ [1]. Most of these children will have mild symptoms and they out grow it in course of time. The symptoms can include failure to thrive, attention deficit disorder, behavior problems, enuresis, other sleep disorders like somnambulism, poor academic performance etc. Unlike adults, fewer children with OSA will have excessive daytime sleepiness, with the exception of obese children [2]. AHI of one or more is considered as abnormal in children, where as an AHI of $>5$ is considered as moderate to severe.

The association between OSA and parasomnias is well established. Review of studies shows that about one half of the children referred for evaluation for sleep terror or sleep walking have underlying OSA [3]. OSA in children is most commonly associated with adeno-tonsillar hypertrophy [4]. But not all children with enlarged adenoids and tonsils will have OSA. For the same reason, adeno-tonsillectomy is considered as the first line of management of OSA, even in obese children [5]. As the area of adenoids and the tonsils are more prone for airway collapse, adenotonsillectomy is offered for all children with OSA, even if there is no significant enlargement of these lymphoid tissues. Not all OSA will improve after the surgery. So a repeat sleep study is advisable after the surgery. But the persistence of OSA is usually seen in those with craniofacial abnormalities [6].

First line of management of enlarged tonsil and adenoid is to treat the underlying allergic disease if any, by using corticosteroid nasal spray and anti-histamine. Even though OSA is a serious complication of adeno-tonsil hypertrophy, where an adeno-tonsillectomy is indicated, this case clearly shows how the initiation of the medications for the allergic disease and its control, can just be enough to manage 
the situation, thus avoiding an invasive procedure, at least in a few children.

\section{Conflict of Interest}

No conflicts of interest.

\section{References}

1. Chan J, Edman JC, Koltai PJ (2004) Obstructive sleep apnea in children AmFam Physician 69: 1147-1155.

2. Gozal D, Wang M, Pope DW (2001) Objective sleepiness measures in pediatric obstructive sleep apnea. Pediatrics 108: 693-697.
3. Guilleminault C, Palombini L, Pelayo R, Chervin RD (2003) Sleepwalking and sleep terrors in prepubertal children: What triggers them? Pediatrics 111: 17-25.

4. Marcus CL, Gipson K, Kinane TB (2019) Sleep-disordered breathing in children.Am J Respir Crit Care Med 164: 16-30.

5. Stradling JR, Thomas G, Warley AR, Williams P, Freeland A (1990) Effect of adenotonsillectomy on nocturnal hypoxaemia, sleep disturbance, and symptoms in snoring children. Lancet 335: 249-253.

6. Contencin P, Guilleminault C, Manach Y (2003) Long-term follow-up and mechanisms of Obstructive Sleep Apnea (OSA) and related syndromes through infancy and childhood.Int J Pediatr Otorhinolaryngol 67: 119-123. 


\section{If}

Advances In Industrial Biotechnology | ISSN: 2639-5665

Advances In Microbiology Research | ISSN: 2689-694X

Archives Of Surgery And Surgical Education | ISSN: 2689-3126

Archives Of Urology

Archives Of Zoological Studies | ISSN: 2640-7779

Current Trends Medical And Biological Engineering

International Journal Of Case Reports And Therapeutic Studies | ISSN: 2689-310X

Journal Of Addiction \& Addictive Disorders | ISSN: 2578-7276

Journal Of Agronomy \& Agricultural Science | ISSN: 2689-8292

Journal Of AIDS Clinical Research \& STDs | ISSN: 2572-7370

Journal Of Alcoholism Drug Abuse \& Substance Dependence | ISSN: 2572-9594

Journal Of Allergy Disorders \& Therapy | ISSN: 2470-749X

Journal Of Alternative Complementary \& Integrative Medicine | ISSN: 2470-7562

Journal Of Alzheimers \& Neurodegenerative Diseases | ISSN: 2572-9608

Journal Of Anesthesia \& Clinical Care | ISSN: 2378-8879

Journal Of Angiology \& Vascular Surgery | ISSN: 2572-7397

Journal Of Animal Research \& Veterinary Science | ISSN: 2639-3751

Journal Of Aquaculture \& Fisheries | ISSN: 2576-5523

Journal Of Atmospheric \& Earth Sciences | ISSN: 2689-8780

Journal Of Biotech Research \& Biochemistry

Journal Of Brain \& Neuroscience Research

Journal Of Cancer Biology \& Treatment | ISSN: 2470-7546

Journal Of Cardiology Study \& Research | ISSN: 2640-768X

Journal Of Cell Biology \& Cell Metabolism | ISSN: 2381-1943

Journal Of Clinical Dermatology \& Therapy | ISSN: 2378-8771

Journal Of Clinical Immunology \& Immunotherapy | ISSN: 2378-8844

Journal Of Clinical Studies \& Medical Case Reports | ISSN: 2378-8801

Journal Of Community Medicine \& Public Health Care | ISSN: 2381-1978

Journal Of Cytology \& Tissue Biology | ISSN: 2378-9107

Journal Of Dairy Research \& Technology | ISSN: 2688-9315

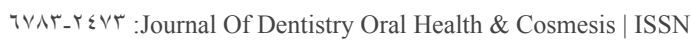

Journal Of Diabetes \& Metabolic Disorders | ISSN: 2381-201X

Journal Of Emergency Medicine Trauma \& Surgical Care | ISSN: 2378-8798

Journal Of Environmental Science Current Research | ISSN: 2643-5020

Journal Of Food Science \& Nutrition | ISSN: 2470-1076

Journal Of Forensic Legal \& Investigative Sciences | ISSN: 2473-733X

Journal Of Gastroenterology \& Hepatology Research | ISSN: 2574-2566
Journal Of Genetics \& Genomic Sciences | ISSN: 2574-2485

Journal Of Gerontology \& Geriatric Medicine | ISSN: 2381-8662

Journal Of Hematology Blood Transfusion \& Disorders | ISSN: 2572-2999

Journal Of Hospice \& Palliative Medical Care

Journal Of Human Endocrinology | ISSN: 2572-9640

Journal Of Infectious \& Non Infectious Diseases | ISSN: 2381-8654

Journal Of Internal Medicine \& Primary Healthcare | ISSN: 2574-2493

Journal Of Light \& Laser Current Trends

Journal Of Medicine Study \& Research | ISSN: 2639-5657

Journal Of Modern Chemical Sciences

Journal of Nanotechnology Nanomedicine \& Nanobiotechnology | ISSN: 2381-2044

Journal Of Neonatology \& Clinical Pediatrics | ISSN: 2378-878X

Journal Of Nephrology \& Renal Therapy | ISSN: 2473-7313

Journal Of Non Invasive Vascular Investigation | ISSN: 2572-7400

Journal Of Nuclear Medicine Radiology \& Radiation Therapy | ISSN: 2572-7419

Journal Of Obesity \& Weight Loss | ISSN: 2473-7372

Journal Of Ophthalmology \& Clinical Research | ISSN: 2378-8887

Journal Of Orthopedic Research \& Physiotherapy | ISSN: 2381-2052

Journal Of Otolaryngology Head \& Neck Surgery | ISSN: 2573-010X

Journal Of Pathology Clinical \& Medical Research

๑ รุ_หษ १: Journal Of Pharmacology Pharmaceutics \& Pharmacovigilance | ISSN

Journal Of Physical Medicine Rehabilitation \& Disabilities | ISSN: 2381-8670

Journal Of Plant Science Current Research | ISSN: 2639-3743

Journal Of Practical \& Professional Nursing | ISSN: 2639-5681

Journal Of Protein Research \& Bioinformatics

Journal Of Psychiatry Depression \& Anxiety | ISSN: 2573-0150

Journal Of Pulmonary Medicine \& Respiratory Research | ISSN: 2573-0177

Journal Of Reproductive Medicine Gynaecology \& Obstetrics | ISSN: 2574-2574

Journal Of Stem Cells Research Development \& Therapy | ISSN: 2381-2060

Journal Of Surgery Current Trends \& Innovations | ISSN: 2578-7284

Journal Of Toxicology Current Research | ISSN: 2639-3735

Journal Of Translational Science And Research

Journal Of Vaccines Research \& Vaccination | ISSN: 2573-0193

Journal Of Virology \& Antivirals

Sports Medicine And Injury Care Journal | ISSN: 2689-8829

Trends In Anatomy \& Physiology | ISSN: 2640-7752

Submit Your Manuscript: http://www.heraldopenaccess.us/Online-Submission.php 